\title{
An uncommon cause of radial access failure
}

\author{
Luis Alvarez-Acosta, Marcos Rodriguez-Esteban, Julio Hernández Afonso
}

Department of Cardiology, Hospital Universitario Nuestra Señora de la Candelaria, Santa Cruz de Tenerife, Spain

\section{Correspondence to Luis Alvarez-Acosta, luisalvaco@gmail.com}

\section{DESCRIPTION}

An 83-year-old woman with a suspected coronary atherosclerotic disease in the setting of severe left ventricular dysfunction underwent a coronary angiography at our institution. Prior to catheterisation, Allen test was performed, which showed normal bilateral circulation. Using a $5 \mathrm{Fr}$ catheter sheath through the right radial artery, we found a guide wire blockage at the axillary artery level. Recanalisation of prior arterial occlusion with collateral circulation was found during the angiography (figure 1 and video 1). Deeper background investigations were performed discovering a right humerus neck fracture that occured 10 years ago and was conservatively treated. Radial access is a well-known arterial access to perform coronary catheterisation in which the main cause of access

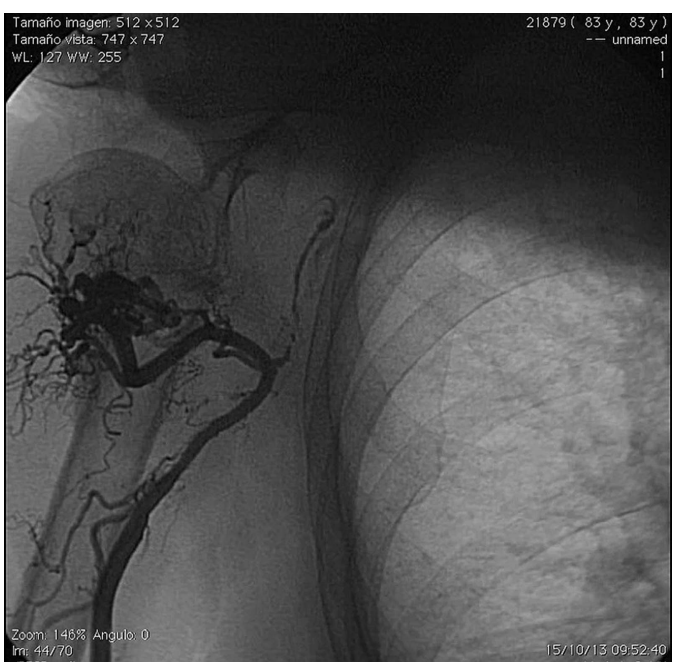

Figure 1 Radial artery blockage and collateral flow.

failure is radial spasm. ${ }^{1}$ In this case, we show an extremely rare cause of access failure secondary to a traumatic injury of the axillary artery. ${ }^{2}$ Collateral flow development allowed distal perfusion of the subsequent arteries, masking such injury during the Allen test. In our opinion, anamnesis is always an important tool to avoid any medical complication and specifically trauma injuries must always be considered. We recommend performing an angiography in the case of any difficulty during catheterisation. It is important to avoid any damage

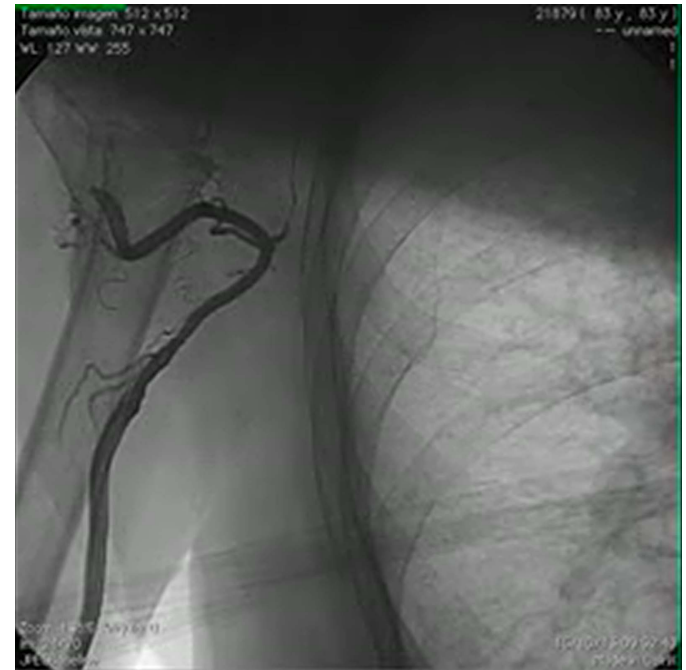

Video 1 Angiography of the radial artery.

in such an injured artery, otherwise it would lead to devastating consequences.

\section{Learning points}

- Prior anamnesis is vital in order to avoid artery access complications.

- Allen test does not discard artery injuries with collateral flow prior to the radial artery.

- Axillary artery injury is a possible cause to radial access failure.

Contributors LA-A wrote the first version of the manuscript and the questions. MR-E performed the supervision of the manuscript, gave expert opinion, looked for the images and corrected the final version. JHA supervised all the process, gave expert opinion and gave final approval for the version of the manuscript.

Competing interests None.

Patient consent Obtained.

Provenance and peer review Not commissioned; externally peer reviewed.

\section{REFERENCES}

1 Bernat I, Horak D, Stasek J, et al. ST elevation myocardial infarction treated by RADIAL or femoral approach in a multicenter randomized clinical trial: the STEMI-RADIAL trial. J Am Coll Cardiol Published Online First: 6 Nov 2013. doi:10.1016/j.jacc.2013.08.1651

2 Byrd RG, Byrd RP Jr, Roy TM. Axillary artery injuries after proximal fracture of the humerus. Am J Emerg Med 1998;16:154-6. 
Copyright 2014 BMJ Publishing Group. All rights reserved. For permission to reuse any of this content visit http://group.bmj.com/group/rights-licensing/permissions.

BMJ Case Report Fellows may re-use this article for personal use and teaching without any further permission.

Become a Fellow of BMJ Case Reports today and you can:

- Submit as many cases as you like

- Enjoy fast sympathetic peer review and rapid publication of accepted articles

- Access all the published articles

- Re-use any of the published material for personal use and teaching without further permission

For information on Institutional Fellowships contact consortiasales@bmjgroup.com

Visit casereports.bmj.com for more articles like this and to become a Fellow 